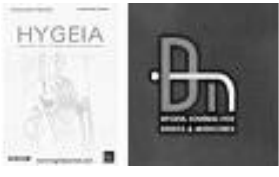

\title{
Studies on the Plant diversity of Muniandavar Sacred Groves of Thiruvaiyaru, Thanjavur, Tamil Nadu, India
}

\author{
J.Jayapal $^{1}$, A.C.Tangavelou ${ }^{2}$, and A.Panneerselvam ${ }^{1}$ \\ 1. P.G. Research Dept. of Botany and Microbiology, A.V.V.M. Sri Pushpam College (Autonomous), Poondi- \\ 613503 Thanjavur (Dist.). Tamil Nadu, India. \\ 2. Bio-Science Research Foundation, Pondicherry, India- 605010.
}

Article history: Received: 18 October 2013, revised: 10 November 2013, accepted: 10 January 2014, Available online: 3 April 2014

\begin{abstract}
Plan: Muniandavar Sacred Groves from Vaduvakudi at Thiruvaiyaru Taluk, Thanjavur district of Tamil Nadu was selected for floristic exploration to know the plant diversity of the vegetation, the availability of rare and endangered floras, the ecological significance, regeneration status and the anthropogenic pressures, to document the religious beliefs and spirituality and the participation of locals on conservation.

Outcome : In the present study, the flora of Muniandavar Sacred Groves comprises about 180 plant species belonging to 158 genera and 75 plant families, Key stone species available in the Sacred groves includes Anacardium occidentale, Borassus flabellifer, Ficus benghalensis that harbors a number of birds and other survival of many other species. Muniandavar sacred grove is in good vegetation status and the conservationists should take necessary action to protect this grove from plastic pollution. An environmental awareness programme is planned to conduct for the local people in order to safeguard this sacred grove from pollution.
\end{abstract}

Keywords: Sacred groves, Medicinal Plant, Anthropogenic Pressure, Key Stone species, Conservation.

\section{INTRODUCTION}

Since time immemorial, conservation of natural resources has been an integral part of several indigenous communities. Nature worship has been a key force in determining human attitudes towards conservation and sustainable utilization of biodiversity ${ }^{34}$. Various indigenous communities all over the world lived in harmony with nature and thus conserved biodiversity. Furthermore, habitat alteration, over-exploitation, pollution and introduction of exotic species also threatened the global biological resources. This has led to the fast depletion of biodiversity in different ecosystems and adversely affected the ecological balance and socioeconomic status of the people. These directly or indirectly contribute to the welfare and stability of the environment and society.

Many traditional conservation practices of indigenous people in many parts of the world such as protection of small forest patches by dedicating them to the local deity, also contributed to the conservation and protection of biodiversity ${ }^{39,15,22,35}$. 
Such forest patches called Sacred Groves are tracts of virgin forest harboring rich biodiversity, protected by the local people based on their indigenous cultural and religious beliefs and taboos.

Sacred Groves are patches of natural vegetation surviving in the man-modified landscapes. They owe their preservation to their perceived importance to some form of divinity. ${ }^{\mathbf{2 6}}$ define 'Sacred Groves' as segments of landscape containing trees and other forms of life and geographical features, that are delimited and protected by human societies believing that preserving such a patch of vegetation in a relatively undisturbed state is necessary for expressing one's relation to the divine or to nature. So these remain as isolated patches of forests in the midst of agricultural landscapes ${ }^{14,15,5,36,54,38,57,60,3,40}$. They are the repositories of rare and endemic species and can be regarded as the remnants of the primary forest left untouched by the local inhabitants due to the belief that deities reside in these forests.

Various communities in India follow nature-worship based on the premise that all creations of nature have to be protected. As a result, sacred groves still possess a great heritage of diverse gene pool of many forest species having socio-religious attachment and possessing medicinal values. There exist some fascinating examples of forest patches harboring native vegetation ${ }^{14}$. Various traditional approaches to conservation of nature require a belief system, which includes a number of prescriptions and proscriptions for restrained resource use ${ }^{\mathbf{1 6}}$. The historical links of sacred groves have been traced ${ }^{15}$, the pre-agricultural, hunting and gathering stage of societies, when human society was in its primitive state. Sacred groves are found in Africa, Asia, Europe, Australia and America ${ }^{16}$. Their existence has also been reported in Ghana, Syria, Nigeria, Turkey and Japan.

In India, Sacred Groves exist in 19 out of 28 states, and it was estimated that there are between $1,00,000-1,50,000$ throughout the country ${ }^{41}$. The number of Sacred Groves reported from various states are Andhra Pradesh $-750^{53}$, Arunachal Pradesh $-65^{12}$, Assam - 40, Chhattisgarh - 600, Gujarat - 29, Haryana - 248, Himachal Pradesh $-5,000$, Jharkhand $-21^{9}$, Karnataka $(1,424)^{27}$, Kerala - 2000), Maharashtra $(1,600)^{67}$, Manipur $-365^{34}$, Meghalaya $-79^{63}$, Orissa - 322, Pondicherry $-15^{57}$, Rajasthan -9 , Sikkim $-56^{11}$, Tamil Nadu $-503^{1}$, Uttarkhand $-12^{2}$ and West Bengal $-670^{1}$ respectively.

In Tamil Nadu, two important traditions namely Kovilkadu meaning sacred grove and Sthalavriksha, which are sacred tree, protected all over the state. Totally 503 groves have been reported from 32 districts of the state ${ }^{1}$. C.P.R. Environmental Education Centre took up a survey of Sacred Groves in Tamil Nadu in April 1997 reported nearly 27 sacred groves have been reported from Pudukottai district which covers an area of about 11.41 hectares in total. Eastern Ghats which lack any forest cover have a large number of sacred groves than the forested districts on the western side and more than 250 Sthalavrikshas belongs to more than 70 species, of which most of them are trees while few are herbs have been documented. While it is difficult to determine the origins of the tradition of conserving sacred groves without historical evidence, it is thought that this dates back to pre-agrarian societies $^{39}$. With the advent of agriculture, people may have set aside patches of natural habitats that were considered sacred, while surrounding forests were cleared for cultivation ${ }^{\mathbf{1 6}}$. The subsequent increase in population may have compelled people to use these sites for day-to-day purposes, such as fuel and food collection. It would appear that the origin of the groves was not necessarily for utilitarian purposes, but utility may have emerged as a result of their presence in the landscape. 
This may have led, in turn, to the strengthening of a "social fence" in order to prevent unreasonable exploitation of the resources within these forest patches. This social fence now provides protection for a variety of species and habitats, as described in the examples below. In the dry regions of central India, some perennial hill streams and riparian gallery forests receive protection as a result of religionbased traditions.

In a village in the Koraput district (Orissa state), for example, there is a shrine hidden under stones within some bushes that grow among tall trees. While the surrounding land is barren, the trees in the vicinity of the shrine have remained untouched and protected because the shrine is considered sacred by the local community ${ }^{62}$. Protection of trees for religious reasons is common in southern India. Near the town of Madurai (Tamil Nadu), groups of tall trees at four separate sites are considered sacred. These tree groves provide roosting sites for colonies of the Indian flying fox (Pteropus giganteus). It is believed that this bat, which elsewhere is hunted for its body fat (for use in alternative medicines), receives protection because the trees are worshipped by the local people ${ }^{32}$. The sprinkling of saffron water around a piece of land is a common practice in Udaipur district (Rajasthan) in northwestern India $^{18}$. The attempts of the local forest department to conserve an area of forest at a site near Udaipur were largely unsuccessful because of persistent transgressions by local people. Frustrated, the forest officers decided to sprinkle saffron water around the site, in accordance with the local tradition. This was greeted with enthusiasm, and subsequently the local people began to respect the boundaries of the conservation area ${ }^{18}$. Such social taboos exist in most cultures, so that informal practices rather than laws determine human behavior ${ }^{10}$. There are a number of examples where part or all of a terrestrial or aquatic landscape may never be subjected to resource use ${ }^{\mathbf{1 0}}$.

These restrictions may not be specifically designed for nature conservation; instead, the motivation is based on traditions, practices, and beliefs passed down through generations ${ }^{4}$. The rationale for sacred grove conservation is therefore very different from the rationale for setting aside formal protected areas. Furthermore, enforcement and sanctioning mechanisms are also different. Formal protection depends on legal frameworks and a large number of officers to enforce the laws, while informal nature conservation is mostly enforced by community members. The former system can be expensive, while the latter is carried out voluntarily and costs little or nothing ${ }^{47}$. The international conservation community has largely failed to recognize this approach. The Integrated Conservation and Development Projects (ICDPs), a form of international aid specifically for conserving natural resources as well as improving quality of life in developing countries, are often criticized for their failures and for their attempts to achieve two very contrasting objectives ${ }^{\mathbf{7 , 3 7}, 48,61}$. However, argue that authoritarian protection practices overlook certain key aspects of social processes that could make conservation work more efficiently ${ }^{\mathbf{8}}$.

The key aspects of non-authoritarian, social regulation of natural resources are acceptance among members of the community, as well as fair enforcement of the agreed rules, strong organizational and institutional arrangements, and constructive dialogue. We agree with ${ }^{8}$, and would further argue that informal conservation traditions also have a high degree of acceptance among local communities. If the merits of such traditions are recognized and legitimized within ICDPs, there is a strong possibility that ICDPs will work much better than they do at present. 


\section{MATERIALS AND METHODS}

\subsection{Study Area}

The study area Muniandavar sacred grove is located at Vadukakudi (Fig -1), nearly $30 \mathrm{~km}$ away from Thanjavur to Thirukkattuppalli road with an area of about 4 hectares. Geographically, it is lying between $10^{\circ} 52^{\prime} 23.9700^{\prime \prime} \mathrm{N}$ latitude and $79^{\circ} 4^{\prime} 31.7676^{\prime \prime}$ E longitude. Temperature is moderately high and the average temperature during summer is $34^{\circ} \mathrm{C}$ and fewer less in winter. The average humidity ranged from 31 to $33 \%$ during November to December.

Annual rainfall is ranging from 850 to $1000 \mathrm{~mm}$. However, during the two decades the district has experienced rainfall only below normal. Most of the rains occur during north east monsoon. Soil is a ferruginous type with admixture of limestone. The soil is shallow in rocky areas and deeper in valley with little or no humus. The vegetation of Muniadndavar Sacred Grove is tropical dry evergreen forest type?. Muniandavar sacred grove is in good vegetation status and the conservationists should take necessary action to protect this grove from plastic pollution.

Fig 1. The study area of Muniandavar sacred grove in Vadukakudi at Thiruvaiyaru Taluk, Thanjavur District

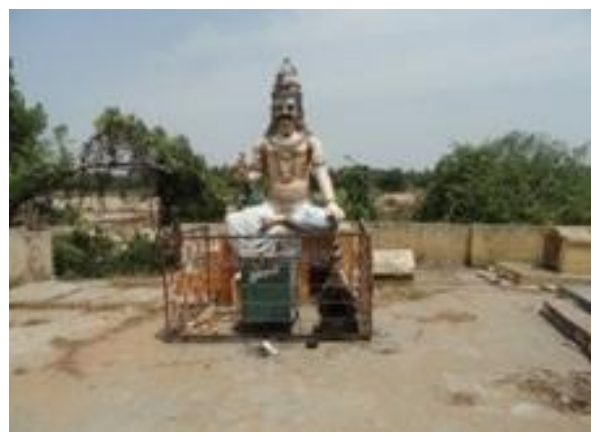

View of the Muniandavar Sacred Groves

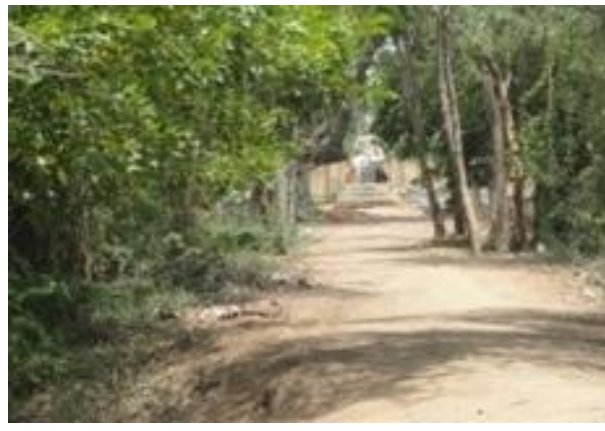

Vegetation of Muniandavar Sacred groves

\section{METHODS}

Regular field visits were made during the year 2011-2012 to explore the floristic composition and the conservation status of the Muniandavar sacred grove of Thiruvaiyaru Taluk from Thanjavur district, Tamilnadu, India. The ethnobotanical survey was carried out among local people in the study area of the Vaduvakudi village. The field visit was conducted several times. Ethnobotanical information was collected according to the questionnaire, interviews and discussion among villagers in their local language. Our questionnaire allowed descriptive response on the plant prescribed, such as part of the plant used in medicinal purpose and collected detailed information. The data was collected from 45 informants between the age of $45-65$ both men and women. Some of them were accompanied us to the sacred grove where showed us plants that are used as medicines Table- 1. Angiosperm plant specimens available in the study areas were collected for authenticity and the herbarium specimens were prepared by following the methodology ${ }^{28}$. Photographs were also taken. The herbarium specimens were identified with the help of Flora of the Presidency of Madras ${ }^{17}$, The Flora of British India ${ }^{25}$ and the Flora of Tamil Nadu ${ }^{44}$. The Flora of Tamil $\mathrm{Nadu}^{23,24,46}$ has been referred for the correct binomial names for the specimens collected. The religious beliefs, spirituality and the participation of locals on conservation on these sacred groves were also documented. 
Herbarium specimens were prepared for all the plants and deposited at the Department of Botany, A.V.V.M. Sri Pushpam College, Thanjavur for reference.

\section{RESULTS}

\section{Floristic Analysis}

In the present study, the flora of Muniandavar Sacred Grove comprises of about totally 180 Angiosperms plant species belonged to 75 families and 158 genera were recorded (Table 1). Among habit wise distribution, herbs were the dominant form represented by $33 \%$ with 60 species followed by trees (31\% with 55 species), shrubs ( $22 \%$ with 40 species), climbing herbs (9\% with 17 species) and climbing shrubs (4\% with 8 species) (Table- 1). Among the top 07 family wise distribution, Euphorbiaceae was the dominant family represented by $22 \%$ with 15 species followed by Acanthaceae (17\% with 11 species), Fabaceae (13\% with 9 species), Mimosaceae (12\% with 8 species each), Rubiaceae and Caesalpiniaceae (11\% with 7 species each) Lamiaceae and Rutaceae (07\% with 5 species) (Table $2 \&$ Table 3). Among top 16 generic wise distribution, the genus such as Euphorbia, Justicia, Cassia, was the dominant genus represented by $10 \%$ with 4 species followed by Barleria, Ruellia, Carrisa, Capparis, Commelina, Jatropha, Indigofera, Hibiscus, Acacia, Albizia, Atalantia, Cissus (5\% with 2 species each) respectively.

Important medicinal plants mentioned in the Indian traditional medicinal system like Ayurveda, Siddha or Ethnomedicine available in this sacred grove are Asparagus racemosus, Bacopa monnieri, Carissa carandas, Centella asiatica, Gloriosa superba etc. and endangered medicinal plants found in this area are Aegle marmelos, Cosinium fenestratum, Gloriosa superba, Strychnos potatorum etc.

\section{DISCUSSION}

Floristic study of vegetation is important to determine the distribution of food plants for wildlife ${ }^{13}$ and prerequisite for much fundamental research in tropical community ${ }^{29}$. The present findings are comparable with other studies in sacred groves of Tamil Nadu and other regions of India. In Tamil Nadu, several studies with respect to floristic inventory were reported includes 260 species in 176 genera and 62 families from Malliganatham ${ }^{30}, 224$ species in 175 genera and 63 families from Vamban $^{31}, 35$ species in 32 genera and 22 families $^{58}, 77$ species in 61 genera and 30 families ${ }^{42}$ from 4 Sacred Groves of Coromandel coast, 265 species from 50 Sacred Groves collectively ${ }^{33}$, 106 species $^{2}$ belonging to 97 genera and 54 families from Manganampatti, Nadiamman and Suranviduthi village ${ }^{66}$ of Pudukottai district, 98 species in 38 families and 76 genera from 33 sacred groves of Theni district $^{43}, 98$ species in 87 genera and 43 families from 11 miniature Sacred Groves ${ }^{59}$ of Kanniyakumari district, 133 plant species from sacred groves in Pallipatty village of Maduari district $^{21}$. In addition $^{55}$ reported 59 species in 55 genera and 30 families from Karaikkal. Woody species diversity of four Sacred Groves in the Pondicherry region ${ }^{52}$. Thus, floristic diversity assessment is significant at local and regional levels to understand the present status and to make effective management strategies for conservation ${ }^{29}$. 
Moreover, the presence of various dry evergreen plant species such as Albizia amara, Atalantia monophylla, Lepizanthes tetraphylla, Madhuca longifolia, Memecylon umbellatum, Morinda pubescens, Pterospermum canescens revealed that the vegetation of the selected sacred groves is a tropical dry evergreen forest type. Similar observations are observed from several sacred groves of adjacent district of Pudukottai ${ }^{33} 64,65$ and Sivagangai district of Tamil Nadu state ${ }^{19,20}$. This is due to the presence of typical, characteristic and preferential evergreen tree species ${ }^{45}$. The presence of big lianas such as Combretum ovalifolium, Mimosa intsia, revealed the undisturbed status of the grove. Key stone species such as Borassus flabellifer, Ficus benghalensis, Memecylon umbellatum found in the grove harbors a number of birds and other survival of many other species ${ }^{33}$. Keystone species play a crucial role in biodiversity conservation through key functions that they perform in an ecosystem often they are also socially or culturally valued ${ }^{49}$, used not only for managing pristine ecosystems ${ }^{51}$ but also for building up biodiversity in both natural and human-managed ecosystems through appropriately conceived rehabilitation strategies that will ensure people's participation ${ }^{50}$. In this grove, the sacred pond was also seen which harbors a variety of fishes and other zooplanktons. The threatened plants recorded from the study area include Aegle marmelos, Gloriosa superba, Madhuca longifolia respectively similar to previous report from Pudukottai district ${ }^{33}$.

\section{Ecological significance}

\subsection{Conservation of Biodiversity}

The sacred groves are important repositories of floral and faunal diversity that have been conserved by local communities in a sustainable manner. They are often the last refuge of endemic species in the geographical region.

\subsection{Recharge of aquifers}

The groves are often associated with ponds, streams or springs, which help meet the water requirements of the local people. The vegetative cover also helps in the recharging the aquifers.

\subsection{Soil conservation}

The vegetation cover of the sacred groves improves the soil stability of the area and also prevents soil erosion.

\subsection{Vegetation}

The vegetation of the selected sacred groves are of tropical dry evergreen forest type comprises the species include Albizia amara, Atalantia monophylla, Crateva magna, Euphorbia antiquorrum, Memecylon umbellatum, Morinda pubescens, Pongamia pinnata, Pterospermum canescens, Stychnos nux-vomica etc. The presence of big lianas such as Ventilago maderaspatana, Mimosa intsia and Combretum albidum revealed the undisturbed status of the vegetation.

\subsection{Key stone species}

Key stone species available Muniandavar Sacred Groves includes Anacardium occidentale, Borassus flabellifer, Ficus benghalensis, and Memecylon umbellatum that harbors a number of birds and other survival of many other species. The sacred pond harbors a variety of fishes and other zooplanktons. 


\begin{tabular}{|c|c|c|c|c|c|}
\hline Herbarium No. & Botanical Names & Family & Habit & Extracts of the plant parts used & Uses \\
\hline JJAP93 & Abrus precatorius L. ssp. Precatorius & Fabaceae & Climbing herb & Leaves, seed & Joint pain, paralysis \\
\hline JJAP119 & Abutilon indicum (L.). ssp. Indicum & Malvaceae & Shrub & Seeds & Cough and fever. \\
\hline JJAP128 & Acacia nilotica (L.) Del. indica (Benth) Brenan & Mimosaceae & Tree & Roots, leaves, Seeds & Diarrhoea and dysentery \\
\hline JJAP129 & Acacia polyacantha willd. & Mimosaceae & Tree & Root, leaves & Snakebites, gonorrhea, venereal diseases, dysentery and gastrointestinal disorders. \\
\hline JJAP78 & Acalypha indica $\mathrm{L}$. & Euphorbiaceae & Herb & Whole plant & Anthelmentic, mental for emetic, earache and skin disease \\
\hline JJAP18 & Acanthospermum hispidum DC. & Amaranthaceae & Herb & Leaves & $\begin{array}{l}\text { Antimalarial properties } \\
\text {. }\end{array}$ \\
\hline JJAP12 & Actiniopteris radiata (Koenig \& Swarts) & Actiniopteridaceae & Herb & Whole plant & Blood pressure, cough and tuberculosis \\
\hline JJAP19 & Aegle marmelos (L.) Corr. & Amaranthaceae & Tree & Fruit, bark & $\begin{array}{l}\text { Diarrhoea, constipation. } \\
\text {. }\end{array}$ \\
\hline JJAP161 & Aerva lanata (L.) A.L.Juss. & Rutaceae & Herb & Whole plant & Cure kidney stones, headache, demulcent, diuretic. \\
\hline JJAP94 & Aeschynomene aspera $\mathrm{L}$. & Fabaceae & Shrub & Whole plant & $\begin{array}{l}\text { Tuberculosis, skin infections } \\
\text { Theritis. }\end{array}$ \\
\hline JJAP13 & Agave americana $\mathrm{L}$ & Agavaceae & Shrub & Leaves, root & $\begin{array}{l}\text { Diarrhoea, dysentery, antiseptic, diaphoretic, diuretic and laxative, indigestion, } \\
\text { flatulence, constipation and jaundice. }\end{array}$ \\
\hline JJAP39 & Ageratum conyzoides $\mathrm{L}$. & Asteraceae & Shrub & The whole plant & Purgative, Carminative, laxative, cough, Asthma, bronchitis, leprosy \\
\hline JJAP125 & Aglaia elaeganoidea var. courtallensis & Meliaceae & Tree & Leaves, fruit, seed & $\begin{array}{l}\text { Antidiarrhoeal, alterative, astringent, tonic, employed in leprosy, burning sensation of the } \\
\text { body, inflammations and febrile complaints and painful maturation }\end{array}$ \\
\hline JJAP16 & Alangium salvifolium (L.f.) wangerin. & Alangiaceae & Tree & Root, leaves, bark, fruits and seeds & Laxative, astringent, pungent and purgative \\
\hline JJAP130 & Albizia amara (Roxb.) Boivin & Mimosaceae & Tree & The whole plant & Antiseptic Property \\
\hline JJAP131 & Albizia lebbeck (L.) Benth. & Mimosaceae & Tree & The whole plant & Antiseptic Property \\
\hline JJAP17 & Aloe vera $($ L.)Burm.f. & Aloeaceae & Herb & Whole plant & Astringent, Cooling, vermifuge and Diuretic \\
\hline JJAP20 & Alternanthera sessilis (L.) R.Br.ex DC. & Amaranthaceae & Herb & Whole plant & Diarrhoea, dysentery, stomach disorder, wounded skin, snake bite and fever. \\
\hline JJAP95 & Alysicarpus monilifer (L.) DC. & Fabaceae & Herb & Aerial parts & Anti-inflammatory and in stomach-ache \\
\hline JJAP22 & Anacardium occidentale $\mathrm{L}$. & Anacardiaceae & Tree & Root & Cough leaves: anticancer \\
\hline JJAP107 & Anisochilus carnosus (L.f.) wallich. & Lamiaceae & Herb & Whole plant & Anti- inflammation in liver \\
\hline JJAP149 & Aristida adscensionis.L.Var.adscensienis & 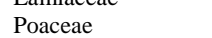 & Herb & Leaves & Antifungal and antimicrobial diseases \\
\hline JJAP34 & Aristolochia indica $\mathrm{L}$. & Aristolochiaceae & Climbing herb & Leaf & Liver disorder. \\
\hline JJAP38 & Asparagus racemosus Willd. & Asparagaceae & Climbing herb & Leaves, flowers and fruits & Hyperacidity, health tonic and uterine tonic \\
\hline JJAP162 & Atalantia monophylla (L.) Corr. Serr. & Rutaceae & Tree & Leaves, root & Fever, skin problem, snake bite, \\
\hline JJAP163 & Atalantia racemosa Wight\&Arn & Rutaceae & Tree & Leaf, rhizome, Seed & Inflammation, diarrhea, paralysis and chronic rheumatism \\
\hline JJAP26 & Atrabotrys odorotissimus $\mathrm{R} . \mathrm{Br}$. & Annonaceae & Climbing shrub & Flowers & Aromatherapy \\
\hline JJAP126 & Azadiracta indica Adr.Juss. & Meliaceae & Tree & Whole plant & $\begin{array}{l}\text { Cooling, } \\
\text { Pngtizer }\end{array}$ \\
\hline JJAP166 & Azima tetracantha $\mathrm{Lam}$. & Salvadoraceae & Tree & Leaves & $\begin{array}{l}\text { Appetizer, laxative., analgesic, epilepsy, hypertensive } \\
\text { Snake bite, stmoach pain, earache }\end{array}$ \\
\hline JJAP172 & Bacopa monneri (L.) Pennell. & Scrophulariaceae & Herb & Whole plant & Nervous, memory enhancer, mental disorder. \\
\hline JJAP150 & Bambusa arundinacea (Retz.) Willd. & Poaceae & Tree & Leaf, root, shoot and seed & $\begin{array}{l}\text { Anti-inflammatory, antiulcer, anti-diabetic, anti-oxidant, } \\
\text { Anthelmintic, antifertility, antibacterial, insectisidal and antiarthritic }\end{array}$ \\
\hline JJAP01 & Barleria buxifolia $\mathrm{L}$. & Acanthaceae & Herb & Roots and leaves & 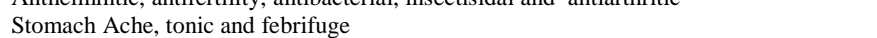 \\
\hline JJAP02 & Barleria cuspidata Hegne ex Nees. & Acanthaceae & Herb & Leaves & Toothaches \\
\hline JJAP47 & $\begin{array}{l}\text { Bauhinia racemosa Lam. } \\
\text { Lames. }\end{array}$ & Caesalpiniaceae & Tree & Roots and leaves: & Stomach Ache, tonic and febrifuge \\
\hline JJAP154 & Benkara malabarica $($ Lam.)Tirv. & Rubiaceae & Tree & Whole plant & Abdominal pain and throat infections \\
\hline JJAP03 & Blepharis maderaspatensis (L.) Roth & Acanthaceae & Herb & Leaves & Bone fracture And deep cuts. \\
\hline JJAP141 & Boerhavia diffusa $\mathrm{L}$. & Nyctaginaceae & Herb & Root, leaves & Jaundice, child birth Liver complaints \\
\hline JJAP31 & Borassus flabellifer $\mathrm{L}$. & Arecaceae & Tree & Root & Cooling, diuretic and Stimulant leaves: cough \\
\hline JJAP79 & Breynia retusa (Dennst.) Alston & Euphorbiaceae & Tree & Leaves, root & Head ache, leaves are used to relieve skin inflammation and meningitis. \\
\hline JJAP54 & Cadapa fruticosa $(\mathrm{L}$.) Druce. & Capparaceae & Shrub & Leaves & Cure gonorrhea \\
\hline JJAP35 & Calotropis procera (Aiton) W.T. Aiton & Asclepiadaceae & Shrub & Root, bark & Paralysis, Swelling and Intermittent fever Flowers: stomachache \\
\hline JJAP155 & Canthium dicoccum (Gaerter) teijsm \& Binnend & Rubiaceae & Shrub & Bark & Febrifuge and applied externally in fractures \\
\hline JJAP55 & Capparis trifoliata Roxb. & Capparaceae & Shrub & Roots, leaves and seeds & Rheumatism., strangury and inflammation \\
\hline JJAP56 & Capparis brevispina DC. & Capparaceae & Shrub & Root bark, stem, leaf & Urinary and kidney, sexual problems, jaundice and liver disorders \\
\hline JJAP36 & Caralluma attenuata Wigh. \& Arn. & Asclepiadaceae & Herb & WholePlant & Antinociceptic and anti-inflammatory, aralysis, joint pain and fever. \\
\hline JJAP167 & Cardiospermum halicacabumL. Var. lurid(Blume) & Sapindaceae & Climbing herb & Whole Plant & Stomach in pregnant women \\
\hline JJAP41 & $\begin{array}{l}\text { Carmona retusa (Vahl) Masam. } \\
\text {. }\end{array}$ & Boraginaceae & Shrub & Leaves & Cough, colic, diarrhea and dysentery \\
\hline JJAP28 & Carrisa carandus $\mathrm{L}$. & Apocynaceae & Shrub & Root, fruits & Stomach disorder, skin diseases and Burning Sensation \\
\hline JJAP29 & Carrisa spinarum $\mathrm{L}$. & Apocynaceae & Shrub & Leaves, root & Rheumatism, purgative \\
\hline JJAP48 & Cassia auriculata $\mathrm{L}$. & Caesalpiniaceae & Shrub & Roots, leaves and flowers & Diabetes and urinary Troubles. \\
\hline
\end{tabular}




\begin{tabular}{|c|c|c|c|c|c|}
\hline JJAP49 & Cassia fistula $\mathrm{L}$. & Caesalpiniaceae & Tree & Bark & Diabetes and liver disorder. \\
\hline JJAP50 & Cassia occidentalis $\mathrm{L}$. & Caesalpiniaceae & Herb & Seed & Cough, reduce fat from the body \\
\hline JJAP51 & Cassia tora $\mathrm{L}$. & Caesalpiniaceae & Herb & Leaves & Swellings \\
\hline JJAP58 & Cassine glauca ( Rottb) Kuntze. Var. glauca & Celastraceae & Tree & Leaves, root & Snake bite, swelling, headache \\
\hline JJAP113 & Cassytha filiformis $\mathrm{L}$. & Lauraceae & Climbing herb & Whole plant & Tonic, alterative, in bilious affections, chronic dysentery, urethiritis and skin problem \\
\hline JJAP30 & Catharanthes roseus $(\mathrm{L}$.$) Don.$ & Apocynaceae & Herb & $\begin{array}{l}\text { Root, } \\
\text { Leaves., oil }\end{array}$ & Leukemia, breast Cancer, Other related problems, sedative and Stomach ache \\
\hline JJAP156 & Catunaregam dumetorum (Retz) Tirv. & Rubiaceae & Shrub & Leaves, root & Fever, body pins \\
\hline JJAP71 & Cayratia pedata(Lour) A. L. Juss. & Cucurbitaceae & Climbing herb & Tuber & Snake bite \\
\hline JJAP27 & Centella asiatica (L.) Urban & Apiaceae & Herb & Whole Plant & $\begin{array}{l}\text { Diuretic, alternative, Skin diseases, leprosy Powdered leaves: improve Memory power } \\
\text { and Concentration of mind }\end{array}$ \\
\hline JJAP44 & Cereus pterogonus Lemaire. & Cactaceae & Shrub & Young stem & Cardiac stimulant, dropsy \\
\hline JJAP61 & Cheilanthes mysorensis Wall ex beddome & Cheilanthaceae & Shrub & Flowers. Root tuber & Healing \\
\hline JJAP103 & Chloroxylon swietienia DC. & Flindersiaceae & Tree & Whole plant & Antimicrobial, antifertility, analgesic \\
\hline JJAP127 & Cissampelos pariera $\mathrm{L}$. Var. hisuta (DC.) Forman. & Menispermaceae & Climbing herb & Seeds & Snakebite \\
\hline JJAP179 & Cissus pallida Planchon & Vitaceae & Climbing herb & Leaves & Anti-inflammatory activity, phlogistic agents \\
\hline JJAP1180 & Cissus quadrangularis $\mathrm{L}$. & Vitaceae & Climbing shrub & Shoot, root & Digestive troubles, helminithiasia, bone fracture \\
\hline JJAP72 & Citrullus colocynthes (L.) Schrader & Cucurbitaceae & Climbing herb & Leaves & Diabetes, hair falling \\
\hline JJAP164 & Clausena dentate (Willd.) Roemer & $\begin{array}{l}\text { Rutaceae } \\
\text { Ruch }\end{array}$ & Shrub & Leaves and fruits & Anesthetized rats \\
\hline JJAP80 & Cleistanthus collinus (Roxb) Benth. ex Hook. F & Euphorbiaceae & Tree & Leaves & Homicidal \\
\hline JJAP62 & Cleome viscosa $\mathrm{L}$. & Cleomaceae & Herb & Leaves, seed & Earache, eye troubles, skin diseases \\
\hline JJAP177 & Clerodendron inerme (L.) Gaertner & Verbenaceae & Shrub & Leaves & Ringworm \\
\hline JJAP73 & Coccinia indica Wight \& Arn. & Cucurbitaceae & Climbing herb & Fruits & Treat leprosy, fever, asthma, bronchitis \\
\hline JJAP74 & Cocculus hirsutus(L.) Diels & Cucurbitaceae & Climbing herb & Root & Acrid, thermogenic, laxative, emollient, alternate and digestive \\
\hline JJAP32 & Cocos nucifera $\mathrm{L}$. & Arecaceae & Tree & Fruit & Diabetes, diarrhea \\
\hline JJAP42 & Coldenia procumbens $\mathrm{L}$. & Boraginaceae & Herb & Leaves & $\begin{array}{l}\text { Rheumatic swellings, swollen knees and joints } \\
\text { Re }\end{array}$ \\
\hline JJAP64 & Combretum ovalifolium Roxb. & Combretaceae & Climbing herb & Leaves & Purgative \\
\hline JJAP66 & Commelina benghalensis $\mathrm{L}$. & Commelinaceae & Herb & Whole plant & Diuretic, febrifuga \\
\hline JJAP67 & Commelina indica $\mathrm{L}$. & Commelinaceae & Herb & Whole plant & Laxative, cure to burn, boils, itches, septic wounds in the breast \\
\hline JJAP114 & Couroupita guianensis Aublet & Lecithidaceae & Tree & Leaves, bark, fruit, roots & $\begin{array}{l}\text { Hypertension, tumors, pain,, inflammation, common cold, stomachache, skin conditions } \\
\text { and wounds, malaria, and toothache. }\end{array}$ \\
\hline JJAP57 & Crateva magna (Lour.) DC. & Capparaceae & Tree & Leaf and bark & Inflammation, urinary disorder, fever, vomiting and gastric irritation \\
\hline JJAP04 & Crossandra infundibuliformis (L.) Nees & Acanthaceae & Herb & Flowers & Wound healing \\
\hline JJAP81 & Croton bonplandianum Baillon & Euphorbiaceae & Herb & Leaf & Wasp sting \\
\hline JJAP106 & Curculigo orchioides Gaertner & Hypoxidaceae & Herb & Whole plant & Filarial, venereal disease and anticancer. \\
\hline JJAP151 & Cympobogon citratus DC (ex Nees) Stapt & 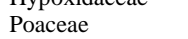 & Herb & Stem & Oral thrush in hiv/aids patients, anxiolytic, hypnotic, and anticonvulsant properties \\
\hline JJAP152 & Cynodon dactylon $(\mathrm{L}$.) Fers & Poaceae & Herb & Grass & Gastric ulcer, bleeding, convulsion, diuretic, skin disease and asthma. \\
\hline JJAP75 & Cyperus rotundus $\mathrm{L}$. & Cyperaceae & Herb & Rhizome, roots & $\begin{array}{l}\text { Stomach disorders, breasts of a mother to promote the milk flow, improve memory and } \\
\text { the cognitive processes, heal wounds indigestion, coughs, bronchitis, to stop vomiting, } \\
\text { spleen and pancreas. }\end{array}$ \\
\hline JJAP73 & Datura metel L. & Solanaceae & Shrub & Seeds & Persistent diarrhoea and dysentery \\
\hline JJAP52 & Delonix elata $($ L.) Gamble & Caesalpiniaceae & 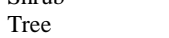 & Leaf and seed & Joint pains and in flatulence reduce to the body \\
\hline JJAP116 & Dendrophthoe falcata (L. f.) Ettingsh & Loranthaceae & Tree & Whole plant & Cooling, bitter, astringent, aphrodisiac and wound healing \\
\hline JJAP96 & Derris scandens (Roxb.) Benth. & Fabaceae & Climbing shrub & Leaves & Anti-inflammatory and gastropathy conditions \\
\hline JJAP132 & Dichrostachys cinerea (L.) Wight\&Arn. & Mimosaceae & Tree & Bark & Dysentery, headaches, toothaches, elephantiasis and acts as a vermifuge \\
\hline JJAP76 & Dioscorea oppositiolia L. & Dioscoreaceae & Climbing herb & Whole plant & Skin disease. \\
\hline JJAP65 & Dodonaea viscosa $\mathrm{L}$. & Combretaceae & Shrub & Leaf and bark & Astringent, healing wounds \\
\hline JJAP82 & Drypetes sepiaria (Wight \& Arn) Pax \& Hoff. & Euphorbiaceae & Tree & Leaves & Anti-inflammatory, cytotoxic and antioxidant effects and liver disease \\
\hline JJAP40 & Eclipta prostrata $(\mathrm{L}.) \mathrm{L}$. & Asteraceae & Herb & Leaves & Hair growth and the black color of our hair \\
\hline JJAP97 & Erythrina varigata $\mathrm{L}$. & Fabaceae & Tree & Leaves and bark & Menstrual disorders fand issures at penis tip \\
\hline JJAP77 & Erythroxylum monogynum Roxb. & Erythroxylaceae & Tree & Bark & Administered orally to cure blood dysentery. \\
\hline JJAP139 & Eucalyptus globulus (Eucall) & Myrtaceae & Tree & Oil & Bronchitis, anti-inflammatory and wounds to prevent infection \\
\hline JJAP140 & Eugenia bracteata (Willd.) Roxb. Ex DC. & Myrtaceae & Tree & $\begin{array}{l}\text { Wood hard, root paste mixed with } \\
\text { goat milk }\end{array}$ & $\begin{array}{l}\text { Tonsils and gum swellings } \\
\text { lata }\end{array}$ \\
\hline JJAP83 & Euphorbia antiquorrum $\mathrm{L}$. & Euphorbiaceae & Shrub & Latex of the branches & Rheumatism, toothache, nervine diseases, dropsy \\
\hline
\end{tabular}




\begin{tabular}{|c|c|c|c|c|c|}
\hline JJAP84 & $\begin{array}{l}\text { Euphorbia hirta } \mathrm{L} \text {. } \\
\text { Euphorbia tirucalli } \mathrm{L} \text {. }\end{array}$ & $\begin{array}{l}\text { Euphorbiaceae } \\
\text { Euphorbiaceae }\end{array}$ & $\begin{array}{l}\text { Herb } \\
\text { Shrub }\end{array}$ & $\begin{array}{l}\text { Whole plant } \\
\text { Whole plant }\end{array}$ & $\begin{array}{l}\text { Leucorrhoea and cool the body } \\
\text { Asthma, cough, earache, neuralgia, rheumatism, toothache, cancer, excrescence, tumors } \\
\text { and warts }\end{array}$ \\
\hline JJAP86 & Euphorbia tortilis Rottler ex Ainslie & Euphorbiaceae & Shrub & Bark, roots, & Irritating to skin and eyes \\
\hline JJAP68 & Evolvulus alsinoides (L.) L. & Convolvulaceae & Herb & Whole plant & Memory enhancement, antiepileptic and immunomodulatory \\
\hline JJAP137 & Ficus benghalensis $\mathrm{L}$. & Moraceae & Tree & Leaf, root and bark & Tooth aches. \\
\hline JJAP102 & Flacourtia indica (Burm.f) Merr. & Flacourtiaceae & Tree & Leaves, bark and roots & Snakebite., arthritis cough, and pneumonia, \\
\hline JJAP63 & Garcinia spicata (Wight \& Art) & Clusiaceae & Tree & Whole plant & Pains and rheumatic swelling \\
\hline JJAP15 & Glinus oppositifolius (L.) DC. & Aizoaceae & Herb & Whole plant & Immune response, like joint pains, inflammations, fever, malaria and wounds \\
\hline JJAP115 & Gloriosa superba $\mathrm{L}$. & Liliaceae & Climbing herb & Whole plant & $\begin{array}{l}\text { Gout, infertility, open wounds, , typhus, itching, leprosy, bruises, sprains, hemorrhoids, } \\
\text { cancer, impotence, nocturnal emission, smallpox, sexually transmitted diseases,, } \\
\text { childbirth to reduce pain snakebite, ulcers, arthritis, cholera,colic, kidney problems }\end{array}$ \\
\hline JJAP165 & Glycosmis pentaphylla (Retz) DC. & Rutaceae & Shrub & Root and leaves & Diarrhoea, coughs, rheumatism, anemia and jaundice \\
\hline JJAP21 & Gomphrena decumbens auct.non Jacq. & Amaranthaceae & Herb & Root & Diabetes \\
\hline JJAP175 & Grewia tilifolia M.Vahl. & 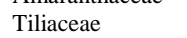 & Tree & Stem bark & Pneumonia, bronchitis and urinary infectious \\
\hline JJAP105 & Gyrocarpus asiaticus Willd. & Hernandiaceae & Tree & Seed and leaves & Bleeding piles. Eye-lotions, haemorrhoids \\
\hline JJAP157 & Hedyotis umbellate $(\mathrm{L}) \mathrm{Lam}$. & Rubiaceae & Herb & Leaf and root & Expectorant and bronchitis \\
\hline JJAP43 & Heliotropium indicum $\mathrm{L}$. & Boraginaceae & Herb & Leaves and young shoots & $\begin{array}{l}\text { Menstruation, wounds, sores, boils, gum-boils and pimples on the face, antiseptic and } \\
\text { anti-inflammation }\end{array}$ \\
\hline JJAP146 & Hemidesmus indicus (L.) R.Br. var. indicus & Periplocaceae & Climbing herb & Whole [plant & Diarrhoea and dysentery \\
\hline JJAP104 & Hemionitis arifolia (Burm.f.) T. Mare & Hemionitidaceae & Herb & Leaves & Hypoglycaemic and anti-diabetes \\
\hline JJAP120 & Hibiscus micranthus L.f. (Dennst) Mabb & Malvaceae & Herb & Roots & Cough \\
\hline JJAP121 & Hibiscus vitifolius $\mathrm{L}$. & Malvaceae & Herb & Roots and leaves & Jaundice, ractured bones and sprained muscles. \\
\hline JJAP118 & Hiptage benghalensis (L.) Kurz & Malphigiaceae & Shrub & Bark, leaves and flowers & $\begin{array}{l}\text { Aromatic, bitter, acrid, stringent, refrigerant, vulnerary, expectorant, cardiotonic, anti- } \\
\text { inflammatory and insecticidal. They are useful in burning sensation, wounds, ulcers, } \\
\text { cough, asthma. }\end{array}$ \\
\hline JJAP176 & Holoptelea integrifolia (Roxb) Planchon & Ulmaceae & Tree & Bark, leaves and flower & 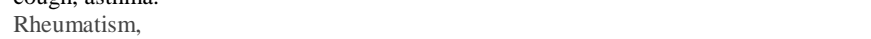 \\
\hline JJAP178 & Hybanthes enneaspermus (L.) F. Muell. & Violaceae & Herb & Whole plant & Aphrodisiac activity; sexual performance;. Sexual arousal \\
\hline JJAP98 & Indigofera aspalathoides M. Vahl. Ex DC. & Fabaceae & Herb & Leaves & Wound healing \\
\hline JJAP99 & Indigofera linnaei Ali & Fabaceae & Herb & The whole plant & $\begin{array}{l}\text { Diuretic } \\
\text { And venereal diseases. }\end{array}$ \\
\hline JJAP05 & Indonesiella echioides (L.) Sreemadh. & Acanthaceae & Herb & Leaves & Diabetes \\
\hline JJAP69 & Ipomoea staphylina Roemer\& schultes. & Convolvulaceae & Shrub & Whole plant & Analgesic \\
\hline JJAP158 & Ixora malabarica & Rubiaceae & Shrub & Whole plant & Dysentery, fever, gonorrhoea, bronchitis \\
\hline JJAP143 & Jasminium angustifolia $(\mathrm{L}$.) Willd. & Oleaceae & Climbing herb & Leaf & Diahhroea \\
\hline JJAP87 & Jatropha glandulfera Roxb. & Euphorbiaceae & Shrub & Leaves & Fever \\
\hline JJAP88 & Jatropha gossypifolia $\mathrm{L}$. & Euphorbiaceae & Shrub & Whole plant & Laxative, increases appetite \\
\hline JJAP06 & Justicia adhatoda $\mathrm{L}$. & Acanthaceae & Shrub & Leaf & Cold and cough \\
\hline JJAP07 & Justicia glauca Rottler & Acanthaceae & Herb & Leaves & Wounds \\
\hline JJAP08 & Justicia simple D.Don. & Acanthaceae & Herb & Leaves & Liver diseases \\
\hline JJAP09 & Justicia tranquebariensis L.f. & Acanthaceae & Herb & Whole plant & Coughs, colds, asthma, skin infections, fevers, and inflammations \\
\hline JJAP23 & Lannea coromendelina (houtt.) Merr. & Anacardiaceae & Tree & Whole plant & Leucoderma, inflammations and skin diseases \\
\hline JJAP117 & Lawsonia inermis $\mathrm{L}$. & Lythraceae & Shrub & Roots & Diarrhoea in babies. \\
\hline JJAP108 & Leonotis nepetifolia (L.) R.Br. & Lamiaceae & Shrub & Leaves & Fever, coughs, womb prolapsed and and malaria \\
\hline JJAP168 & Lepizanthes tetraphylla (M.Vahl) Radlk. & Sapindaceae & Tree & Whole plant & Eczema, psoriasis and for removing frechlets \\
\hline JJAP109 & Leucas aspera (Willd.) Link. & Lamiaceae & Herb & Leaves & Scorpion-sting \\
\hline JJAP133 & Leucena lecophloea $(\mathrm{Lam})$ de Wit & Mimosaceae & Tree & Root and bark & Contraceptive, ecbolic, depilatory \\
\hline JJAP144 & Linociera zeylanica (L) Gamble & Oleaceae & Tree & Leaves & Diabetes \\
\hline JJAP170 & Madhuca longifolia (Koen.) Macbr. & Sapotaceae & Tree & Bark & Astringent and toni fish \\
\hline JJAP24 & Mangifera indica $\mathrm{L}$. & Anacardiaceae & Tree & Bark & Cure dysentery. \\
\hline JJAP123 & Marsilea minuta $\mathrm{L}$. & Marsileaceae & Herb & Whole plant & Insomnia and other mental disorders \\
\hline JJAP59 & Maytenus emarginata (Willd.) Dinhar & Celastraceae & Shrub & Whole plant & Fever, asthama and rheumatism \\
\hline
\end{tabular}




\begin{tabular}{|c|c|c|c|c|c|}
\hline JJAP124 & Memecylon umbellatum Burm.f. & Melastomataceae & Tree & Leaf and root & Conjunctivities, gonorrhea, excessive menstrual discharge \\
\hline JJAP70 & Merremia tridentata $(\mathrm{L}$.$) Hallier.f$ & Convolvulaceae & Herb & Whole plant & Rheumatism, renal function and urinary system \\
\hline JJAP134 & Mimosa intsia $\mathrm{L}$. & Mimosaceae & Climbing shrub & Bark & Astringent properties \\
\hline JJAP171 & Mimusops elengi $\mathrm{L}$. & Sapotaceae & Tree & Leaves and seed & Snake bite, saponin, kernel yields oils \\
\hline JJAP159 & Mitragyna parviflora $\mathrm{L}$. & Rubiaceae & Tree & Leaves, bark, root & Analgesic, antipyretic, anti-inflammatory, antiarthritic, anthelmentic and muscular pain \\
\hline JJAP136 & Mollugo pentaphylla $\mathrm{L}$. & Molluginaceae & Herb & Leaves, fruit & Anti cancer, scabies, tumors and skin disease \\
\hline JJAP160 & Morinda pubescens var. pubescens Roxb. & Rubiaceae & Tree & Leaf and root & Dysentry, duspepsia, fever. \\
\hline JJAP110 & Mucuna pruriens (L.) DC. & Lamiaceae & Herb & Whole plant & Diabetes, high blood pressure \\
\hline JJAP111 & Ocimum tenuiflorum L. & Lamiaceae & Tree & Leaves & Cough, cold and fever. \\
\hline JJAP45 & Olax scandens Roxb. & Cactaceae & Shrub & Bark & Anaemia, diabetes, skin diseases, venereal diseases and respiratory problems \\
\hline JJAP46 & Opuntia dellenii (Ker Gawl.) Haw. & Cactaceae & Shrub & Laef & Asthma, burning, whooping cough and fever \\
\hline JJAP112 & Orthosiphon thrysiflorus (Roth) Slessen & Lamiaceae & Herb & Whole plant & Skin, stomach and lung problems \\
\hline JJAP145 & Pedalium murex $\mathrm{L}$. & Pedaliaceae & Herb & Whole plant & Kidney stone. \\
\hline JJAP37 & Percularia daemia (Forsk) Chiov. & Asclepiadaceae & Climbing herb & Leaves, root & Analgesic activity, cough, biliousness and sore eyes \\
\hline JJAP33 & Phoenix lourieri Kunth. & Arecaceae & Tree & Stem bark & Welling of the joints and as a vermifuge \\
\hline JJAP89 & Phyllanthus amarus Schum\&Thonn & Euphorbiaceae & Herb & Whole plant & Anemic, jaundice, dropsy. \\
\hline JJAP90 & Phyllanthus debilis Klein ex Willd. & Euphorbiaceae & Herb & Whole plant & Diabetes, jaundice, and gonorrhea \\
\hline JJAP91 & Phyllanthus maderaspatensis $\mathrm{L}$. & Euphorbiaceae & Herb & Whole plant & Flu, dropsy, diabetes, jaundice, gall and bladder calculus, liver disease \\
\hline JJAP147 & Piper longum $\mathrm{L}$. & Piperaceae & Climbing shrub & Rhizome & Stomach ache and bronchitis. \\
\hline JJAP142 & Pisonia aculeata $\mathrm{L}$. & Nyctaginaceae & Climbing shrub & Whole plant & Several inflammation, pain, oxidative and liver disorder \\
\hline JJAP135 & Pithecellobium dulce (Roxb) Benth. & Mimosaceae & Tree & Root bark & Dysentery \\
\hline JJAP138 & Plecospermum spinosum Trecul. & Moraceae & Tree & Stem thorn & Checks cholera \\
\hline JJAP148 & Plumbago zeylanica $\mathrm{L}$. & Plumbaginaceae & Shrub & Root, Root, bark & Appetizer,Antibacterial, Anticancer. \\
\hline JJAP100 & Pongamia pinnata 9L) Pierre. & Fabaceae & Tree & Leaves, roots, bark & $\begin{array}{l}\text { Cold, cough, diarrhoea, dyspepsia, flatulence, gonorrhoea and leprosy, gums, teeth and } \\
\text { ulcers, bleeding piles. Juices. }\end{array}$ \\
\hline JJAP101 & Pterolobium hexapetalum (Roxb) Santapau\&Wagh. & Fabaceae & Climbing shrub & Leaves and stem bark & $\begin{array}{l}\text { Fever, tooth ache, chest pain, delivery pains, antidote to dog bite, wound healing, } \\
\text { constipation, piles, ulcers, skin infections, venereal diseases, jaundice and diarrhoea }\end{array}$ \\
\hline JJAP174 & Pterospermum canescens Roxb. & Sterculiaceae & Tree & Flower & Blood troubles, inflammation, ulcers \\
\hline JJAP60 & Reissantia indica (Willd) N.Halle. & Celastraceae & Climbing shrub & Root bark, stem, leaves, & Respiratory troubles, febrifuge, sores and wounds. \\
\hline JJAP25 & Rhus mysorensis Don. & Anacardiaceae & Shrub & Whole plant & Immune-modulating properties \\
\hline JJAP10 & Ruellia prostrate Poir & Acanthaceae & Herb & Leaves & Anti-ulcer \\
\hline JJAP11 & Ruellia tuberose $\mathrm{L}$. & Acanthaceae & Herb & Leaves, root & Kidney stones, fever \\
\hline JJAP14 & Sansevieira roxbhurgiana Schultes \& Schultes. & Agavaceae & Herb & Whole plant & Antibacterial, antioxidant and anticancer properties \\
\hline JJAP169 & Sapindus emarginatus M.Vahl. & Sapindaceae & Tree & Leaves & Soapnuts in treating migraines \\
\hline JJAP153 & Scutia myrtina (Burm.f) Kutz. & Rhamnaceae & Shrub & Whole plant & Anti-inflammatory and antiallergic properties \\
\hline JJAP92 & Secruinega leucopyrus (Willd) Muell. & Euphorbiaceae & Shrub & Whole plant & Sweet, cooling, diuretic, aphrodisiac, tonic \\
\hline JJAP53 & Senna alata (L) & Caesalpiniaceae & Shrub & Leaves, flower & Skin diseases, ring worm, scabies \\
\hline JJAP122 & Sida acuta Burm.f. & Malvaceae & Herb & Root & Disorders, headache, leucorrhoea, Tuberculosis, diabetes, fever and uterine disorders. \\
\hline
\end{tabular}

Table 1. Important Medicinal Plants recorded in Muniandavar Sacred Groves. 
Table. 2. Distribution of top 08 Plant families in Muniandavar Sacred Groves

\begin{tabular}{llcc}
\hline S.No. & \multicolumn{1}{c}{ List offamilies } & No. of species & Percentage (\%) \\
\hline 1 & Euphorbiaceae & 15 & 22 \\
2 & Acanthaceae & 11 & 17 \\
3 & Fabaceae & 09 & 13 \\
4 & Mimosaceae & 08 & 12 \\
5 & Rubiaceae & 07 & 11 \\
6 & Caesalpiniaceae & 07 & 11 \\
7 & Lamiaceae & 05 & 07 \\
8 & Rutaceae & 05 & 07 \\
\hline
\end{tabular}

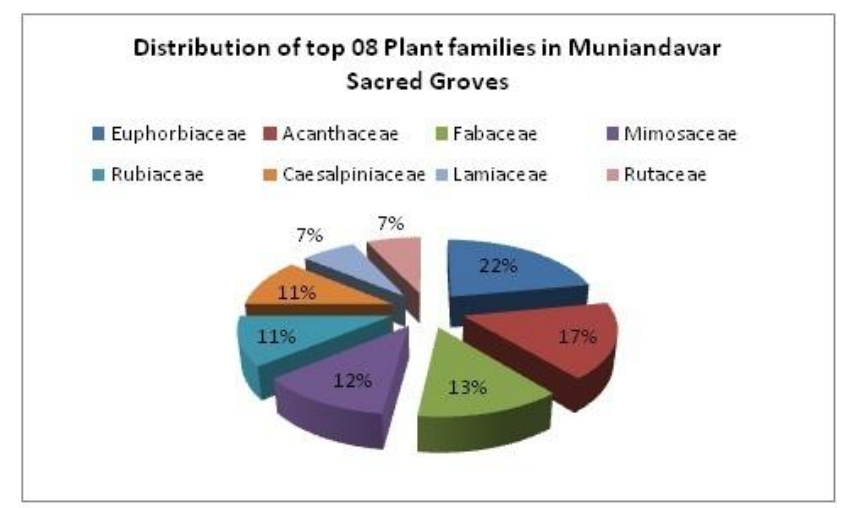

\subsection{Threatened Medicinal Plants}

The threatened medicinal plants recorded from Muniandavar Sacred Groves include Aegle marmelos, Strychnos potatorum, Gloriosa superba, Madhuca longifolia and Piper longum.

\subsection{Religious Spirituality}

The god Muniandavar was worshipped as deity. It was believed that the god Muniandavar is a Kaavalkaaran means Watchman who is watching the people of this territorial region from any evil spirits. Festival during the month of November (Karthigai month in Tamil) is very important festival in this temple. And also, there was a special pooja on Monthly one time. Local people believe that a string tied below the Trishul has the power to do well or to cause harm to an adversary. The sacred is situated under an ironwood tree (Memecylon umbellatum), on which numerous cradles are tied with cloth. This practice is followed in order to be blessed with a child. The thickets of this sacred grove with Muniandavar idol make the people to think good always and the people did not even lie, because telling lie in front of the idol would be punished.

\subsection{Anthropogenic Pressure}

In the study area, the anthropogenic pressures such as collection of firewood, cutting of tree, collections of medicinal plants are not common. Because the people believed that the deity Muniandavar is the owner of this forest and the god may punish immediately those who create any disturbances. The major serious threat to Muniandavar Sacred Groves was environmental pollution by throwing of plastic materials. 
The deities coming from various regions would throw the plastic bags without any mercy in the forest during festival times. This environmental pollution may profoundly disrupt the regeneration status of the vegetation by polluting the soil as well as ground water. Grazing is very common Muniandavar Sacred Groves by livestock animals from local surrounding villages.

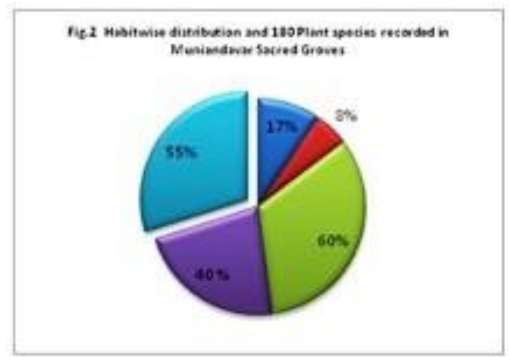

Fig.2.Habit wise distribution and 180 plant species recorded in Muniandavar Sacred Groves

Table 2. List of plant families with number of species distributed in Muniandavar Sacred Grove.

\begin{tabular}{|c|c|c|c|c|c|}
\hline S. No. & Family & No. of species & 17 & Boraginaceae & 03 \\
\hline 1 & Acanthaceae & 11 & 18 & Cactaceae & 03 \\
\hline 2 & Actiniopteridaceae & 01 & 19 & Caesalpiniaceae & 07 \\
\hline 3 & Agavaceae & 02 & 20 & Capparaceae & 04 \\
\hline 4 & Aizoaceae & 01 & 21 & Celastraceae & 03 \\
\hline 6 & Aloeaceae & 01 & 23 & Cleomaceae & 01 \\
\hline 7 & Amaranthaceae & 04 & 24 & Clusiaceae & 01 \\
\hline 8 & Anacardiaceae & 04 & 25 & Combretaceae & 02 \\
\hline 9 & Annonaceae & 01 & 26 & Commelinaceae & 02 \\
\hline 10 & Apiaceae & 01 & 27 & Convolvulaceae & 03 \\
\hline 11 & Apocynaceae & 03 & 28 & Cucurbitaceae & 04 \\
\hline 12 & Arecaceae & 03 & 29 & Cyperaceae & 01 \\
\hline 13 & Aristolochiaceae & 01 & 30 & Dioscoreaceae & 01 \\
\hline 14 & Asclepiadaceae & 03 & 31 & Erythroxylaceae & 01 \\
\hline 15 & Asparagaceae & 01 & 32 & Euphorbiaceae & 15 \\
\hline 16 & Asteraceae & 02 & 33 & Fabaceae & 09 \\
\hline 34 & Flacourtiaceae & 01 & 55 & Nyctaginaceae & 02 \\
\hline 35 & Flindersiaceae & 01 & 56 & Olacaceae & 03 \\
\hline 36 & Hemionitidaceae & 01 & 57 & Pedaliaceae & 01 \\
\hline 37 & Hernandiaceae & 01 & 58 & Periplocaceae & 01 \\
\hline 38 & Hypoxidaceae & 01 & 59 & Piperaceae & 01 \\
\hline 39 & Lamiaceae & 05 & 60 & Plumbaginaceae & 01 \\
\hline 40 & Lauraceae & 01 & 61 & Poaceae & 04 \\
\hline 41 & Lecithidaceae & 01 & 62 & Rhamnaceae & 01 \\
\hline 42 & Liliaceae & 01 & 63 & Rubiaceae & 07 \\
\hline 43 & Loranthaceae & 01 & 64 & Rutaceae & 05 \\
\hline 44 & Lythraceae & 01 & 65 & Salvadoraceae & 01 \\
\hline 45 & Malphigiaceae & 01 & 66 & Sapindaceae & 03 \\
\hline 46 & Malvaceae & 04 & 67 & Sapotaceae & 02 \\
\hline 47 & Marsileaceae & 01 & 68 & Scrophulariaceae & 01 \\
\hline 48 & Melastomataceae & 01 & 69 & Solanaceae & 01 \\
\hline 49 & Meliaceae & 02 & 70 & Sterculiaceae & 01 \\
\hline 50 & Menispermaceae & 01 & 71 & Tiliaceae & 01 \\
\hline 51 & Mimosaceae & 08 & 72 & Ulmaceae & 01 \\
\hline 52 & Molluginaceae & 01 & 73 & Verbenaceae & 01 \\
\hline 53 & Moraceae & 02 & 74 & Violaceae & 01 \\
\hline 54 & Myrtaceae & 02 & 75 & Vitaceae & 02 \\
\hline
\end{tabular}




\section{CONCLUSION}

The present work elucidates the species composition of 180 plant species of flowering plants which spreads in 158 genera and 75 families. The sacred grove with Plant species diversity should be preserved and conserved as a mini spot of biodiversity. Hence exploration and conservation of medicinal plants diversity of these groves is therefore most important for the management and sustainable development in these fragile ecological and life support systems. For this, an environmental awareness programmes should be conducted to the local people regarding the importance and conservation of sacred groves.

\section{ACKNOWLEDGEMENT}

The first and the third author sincerely thank the Secretary and Correspondent and Principal of A.V.V.M. Sri Pushpam College, Poondi, Thanjavur for providing the necessary facilities to carry out this research work.

\section{REFERENCES}

1. Amirthalingam, M., Sacred Groves of Tamil Nadu - A Survey, CPR Environmental Education Centre, Chennai, India, 1998. pp. 191.

2. Anthwal, A., Ramesh C. Sharma, R.C. and Archana Sharma, A., Sacred Groves: Traditional Way of Conserving Plant Diversity in Garhwal Himalaya, Uttaranchal. The Journal of American Science 2006; 2(2): 35-38.

3. Basu R.,Studies on Sacred Groves and Taboos in Purulia District of West Bengal. Indian Forester 2000:1309-1317.

4. Berkes F, Colding J, and Folke C., Rediscovery of traditional ecological knowledge as adaptive management. Ecol Appl. 2000; 10:1251-62.

5. Boojh R. and Ramakrishan P.S., Sacred Groves and their Role in Environmental Conservation. In: Strategies for Environmental Management. Souvenir Vol. Dept. of Science and Environmental of Uttar Pradesh, Luck now, 1983. pp. 6-8.

6. Bhakat, R.K. Socio-religious and ecological perspective of a sacred grove from Midnapore district, West Bengal, Sci. Cult 2003; 69(11-12):371-374

7. Brandon K, Redford KH, and Sanderson SE., Parks in peril: people, politics and protected areas. Washington, DC: The Nature Conservancy and Island Press. 1998.

8. Brechin SR, Wilshusen PR, Fortwangler CL, and West PC., Beyond the square wheel: toward a more comprehensive understanding of biodiversity conservation as social and political process. Soc Natur Resour, 2002;15:41-64.

9. Champion, H.G. and Seth, S.K. A revised survey of the forest types of India. The Manager of Publications, Delhi, 1968.

10. Carrin, M., Santal autonomy as a social ecology, 16th European Conference on Modern South Asian Studies, Edinburgh, 2000.

11. Colding J and Folke C., Social taboos: "invisible" systems of local resource management and biological conservation. Ecol Appl. 2001; 11:584-600.

12. Dash, S.S., Kabi sacred grove of North Sikkim. Current Science 2005; 89(3): 427-428.

13. Dudley, N. Higgins-Zogib, L. and Mansourian, S. The Arguments for Protection Series - Beyond Belief: Linking faiths and protected areas to support biodiversity conservation, 2005 pp. 91-95; World Wide Fund for Nature,

14. Ejtehadi, H, T. Amini and H. Zare. Importance of Vegetation Studies in Conservation of Wildlife: A Case Study in Miankaleh Wildlife Refuge, Mazandaran Province, Iran. Environ. Sci 2005; 9:53-58.

15. Gadgil M. and Vartak V.D. Sacred groves of India - a plea of the continuous conservation. J.Bombay Nat. Hist. Soc. 1975; 72(2): 313-320.

16. Gadgil M. and Vartak V.D. Sacredgroves of Western Ghats of India. Economic Botany 1976; 30: 152 - 160. 
17. Gadgil, M. and Berkes, F. 1991. Resour. Manage.Optim.1991; 8:127-141.

18. Gamble, J.S. and Fischer, C.E.C . Flora of the Presidency of Madras., Vol. 1-3, 1915-1936 , Adlard \& Sons Ltd., London.

19. Gandhi K.. Kesar Chirkav: traditional system of forest protection. Newsletter, Sevamandir. , 1997, Udaipur www.sevamandir.org/Newsletter.htm. Viewed October 2006.

20. Gandhi, K., A.C. Tangavelou and M. Sivaraman. Floristic studies on Kandanur Vaigai Karuppar sacred grove at Sivagangai District, Tamil Nadu. J. Res. Conserv. Biol.2012; 1(2): 055-063.

21. Gandhi, K., A.C. Tangavelou, and M. Sivaraman. Floristic studies on Kaayapatti Kammakaruppar Sacred Grove at Sivagangai district, Tamil Nadu. J. Biosci. Res 2012; 3(3):179-186.

22. Ganesan, S., N. Ponnusamy, L. Kesavan and A. Selvaraj. Floristic composition and practices of the selected sacred groves of Pallipatti Village (Reserve forest), Tamil Nadu. Indian J. Trad. Knowledge, 2007; 8:154-162.

23. Haridasan K. and Rao R.R. Forest .ora of Meghalaya,, Bishen Singh and Mahendrapal Singh, Dehra Dun. Vol. 1, 1985.

24. Henry, A.N., Chithra, V. and Balakrishnan, N.P. Flora of Tamil Nadu. Series 1. Vol. 3. 1989., Botanical survey of India, Coimbatore.

25. Henry, A.N., Kumari, G.R. and Chithra, V, Flora of Tamil Nadu. Series. 1. Vol. 2. , 1987. Botanical Survey of India, Coimbatore.

26. Hooker, J.D. The Flora of British India. Vols. 1-7. 1872-1897, L. Reeve \& Co., London.

27. Hughes D.J. and Subash Chandran M.D., Sacred Groves around the earth: an overview. Paper presented in the workshop on The role of Sacred Groves in conservation and management of Biological Resources, KFRI, Pechi., 1997.

28. Hughes, J.D. and Chandran, M.D.S., Sacred Groves around the earth: an overview. In: Ramakrishnan PS, Saxena KG, and Chandrashekara UM (Eds). Conserving the sacred for biodiversity management. New Delhi, India: Oxford and India Book House., 1998.

29. Jain, S.K. and Rao, R.R. A Handbook of Field and Herbarium Methods. Today and Tomorrow Printers and Publishers, New Delhi., 1976.

30. Jayakumar, S., S. Kim, and J. Heo. Floristic inventory and diversity assessment - A Critical Review. Proc. Inter. Acad. Ecol. Environ. Sci. 2011;1:151-168.

31. John Britto, S., B. Balaguru, S. Soosairaj and D.I. Arockiasamy. Diversity of plants in a sacred grove of Pudukottai District in Tamil Nadu. J. Eco. Taxon. Bot. 2001a; 25: 58-62.

32. John Britto, S., B. Balaguru, S. Soosairaj and D.I. Arockiasamy. 2001b. Floristic analysis of a sacred grove at Vamban in Pudukottai District of Tamil Nadu, South India. J. Eco. Taxon. Bot,2001b;25:81-90.

33. Marimuthu G., The sacred flying fox of India. Bats, 1988;6:10-11.

34. Karthikeyan, S. and A.C. Tangavelou. Journey through Sacred groves. Pondicherry, Bio-Science Research Foundation, 2011.

35. Khumbongmayum, M.D., Khan, M.L. and Tripathi R.S., Sacred Groves of Manipur - Ideal Centres for Biodiversity Conservation. Current Science.2004; 87 (4): 430-433.

36. Khan M.L., Menon S. and Bawa K.S., Effectiveness of the protected area network in biodiversity conservation: a case study of Meghalaya state. Biodiv. Conserv.1997; 6:853-868.

37. Khiewtam R.S. and Ramakrishnan P.S., Sociocultural studies of the sacred groves at Cherrapunji and adjoining areas in North-Eastern India. Man in India. 1989; 69(1):64-71.

38. Kramer RA, van Schaik CP, and Johnson J (Eds)., Last stand: protected areas and the defense of tropical biodiversity. New York, NY: Oxford University Press. 1997.

39. King-Oliver I.E.D., Chitra V. and Narasimha D., Sacred groves: traditional ecological heritage. Int. J. Ecol. Environ. Sci, 1997; 23: 463-470.

40. Kosambi D.D. Myth and Reality.Popular Press, Bombay, India.1962.

41. C.G., Bhagwat S.A. and Kushalapa K.A., Conservation and management of groves of Hodagu, Karnataka, South India - a unique approach. In: Ganeshaiah K.N., Shaanker Uma R. and Bawa K.S. (eds), Tropical Ecosystems: Structure, Diversity and Human Welfare. Oxford IBH Publishing Co. Pvt. Ltd, New Delhi. 2001. pp. 565-569.

42. Malhotra KC, Gokhale Y, and Chatterjee S., Cultural and ecological dimensions of Sacred Groves in India. New Delhi and Bhopal, India: Indian National Science Academy and the Indira Gandhi Rashtriya Manav Sangrahalaya. 2001.

43. Mani, S. and N. Parthasarathy: Tree diversity and stand structure in inland and coastal tropical dry evergreen forests of peninsular India. Curr. Sci, 2006; 90:1238-1246.

44. Manikandan, P., D.R. Venkatesh and K. Muthuchelian: Conservation and Management of Sacred groves in Theni District, Tamil Nadu, India. J. Biosci. Res. 2011; 2:76-80. 
45. Matthew, K.M., Flora of the Tamil Nadu Carnatic. Rapinat Herbarium, Tiruchirappalli, Vol 1-3., 1982.

46. Meher-Homji, V.M: On the origin of the tropical dry evergreen forest of south India. Int. J. Eco. Environ. Sci.1974; 1:19-39.

47. Nair, N.C. and Henry, A.N. 1983. Flora of Tamil Nadu. Ser. 1. Vol. 1. Botanical Survey of India, Coimbatore. Ramakrishnan, P.S: Conserving the sacred: from species to landscapes. Nat. Res.1996; 32:11-19.

48. North DC. Institutions, institutional change and economic performance. Cambridge, UK: Cambridge University Press, 1990.

49. Oates JF. Myth and reality in the rainforest: how conservation strategies are failing in West Africa. Berkeley, CA: University of California Press. 1999.

50. Ramakrishnan, P.S: Increasing population and declining biological resources in the context of global change and globalization. J. Biosci 2001; 26:465-479.

51. Ramakrishnan, P.S: Participatory development in managing population pressure on natural resources. In Growing numbers and dwindling resources (Ed. Krishnan, R.) New Delhi, Tata Energy Research Institute. 1994, pp 86-96.

52. Ramakrishnan, P.S: Shifting agriculture and sustainable development: An interdisciplinary study from north-eastern India, UNESCO-MAB Series, Paris and Parthenon Publ, UK, Carnforth, Lancs. 1992.

53. Ramanujam M.P. and K. Praveen Kumar Cyril, Woody species diversity of four Sacred Groves in the Pondicherry region of South India, Biomedical and Life Sciences and Earth and Environmental Science 2003;12(2):102-114.

54. Ravi Prasad Rao, B. Conservation of threatened flora in Sacred Groves of Southern Andhra Pradesh, Symposium On National Biodiversity and Ecosystem Information Infrastructure (NBEII): Challenges and Potentials, Pune., 2006.

55. Rodgers W.A. The sacred groves of Meghalaya. Man in India, 1994; 74: 339-348.

56. Sambandan, K. and N. Dhatchanamoorthy, Studies on the Phytodiversity of a Sacred Grove and its Traditional Uses in Karaikal District, U.T. Puducherry. J. Phytol.2012;4: 16-21.

57. Sinha B. and Maikhuri R.K. Conservation through 'sociocultural- religious practice' in Garhwal Himalaya: a case study of Hariyali sacred grove'. 1998.

58. Sridhar Reddy, M. and N. Parthasarathy, Liana diversity and distribution on host trees in four inland tropical dry evergreen forests of peninsular India. Trop. Ecol 2006; 47: 109 -123.

59. Sukumaran, S. and S. Jeeva, A floristic study on miniature sacred forests at Agastheeshwaram, southern peninsular India. Eur Asia J. Bio Sci. 2008; 2:66-72.

60. Sunitha S. and Rao R.P.B. Sacred groves in Kurnool District, Andhra Pradesh. In: Sivadasan M. and Philip Mathew (eds), Biodiversity, Taxonomy and Conservation of Flowering Plants. Mentor books, Calicut, 1999, pp. 367-373.

61. Terborgh J. Requiem for nature. Washington, DC: Island Press. 1999.

62. Thusu KN and Jha M. The Ollar Gadaba of Koraput. New Delhi, India: Anthropological Survey of India. Calcutta Memoir No 27. 1969.

63. Upadhaya, K.; Pandey, H.N. 2; Law, P.S. and Tripathi, R.S., Tree diversity in Sacred Groves of the Jaintia hills in Meghalaya, northeast India, Biodiversity and Conservation 2003;12(3): 583-597.

64. Vadivelu, C., A.C. Tangavelou, G. Sivanandhan and N. Selvaraj: Floristic analysis of Perunjunai Sacred Grove from Pudukottai district, Tamil Nadu, India. J. Swamy Bot.Cl 2011a; 28: 71-82.

65. Vadivelu, C., A.C.Tangavelou and N. Selvaraj: Floristic wealth of Madhukaatu Kali Sacred Grove from Pudukottai district. Res. J. Biol. Sci. 2011b; 3(4)19-27.

66. Vinothkumar, D., S. Murugavelu and A. Kethsy Prabhavathy., Phytosociological and Ethnobotanical Studies of Sacred Groves in Pudukottai District, Tamil Nadu, India. Asian J. Exp. Biol. Sci. 2011; 2:306-315.

67. Waghchaure, Chandrakant K., Tetali, Pundarikakshudu; Gunale, Venkat R., Antia, Noshir H., Birdi, Tannaz J., Sacred Groves of Parinche Valley of Pune District of Maharashtra, India and their Importance, Anthropology \& Medicine 2006;13(1):55-76.

J Jayapal, AC.Tangavelou, and A.Panneerselvam. Studies on the Plant diversity of Muniandavar Sacred Groves of Thiruvaiyaru, Thanjavur, Tamil Nadu, India. Hygeia.J.D.Med 2014; 6(1):48-62. Available from http://www.hygeiajournal.com / Article ID- Hygeia.J.D.Med/122/14. D.O.I: 10.15254/H.J.D.Med.6.2014.122 